\title{
Isparta Müzesi’ndeki Yalvaç Yöresi Düz Dokuma Torba Örnekleri
}

\section{The Plain Weaving Carrierbag Samples of Yalvac District in Isparta Museum Bayram DEMIRAL}

Arș. Gör. Dr., Süleyman Demirel Üniversitesi Güzel Sanatlar Fakültesi Geleneksel Türk Sanatları Bölümü email: bayramdemiral@sdu.edu.tr (DORCID ID: https://orcid.org/0000-0001-9500-6728

\section{Naile Rengin OYMAN}

Doç., Süleyman Demirel Üniversitesi Güzel Sanatlar Fakültesi Geleneksel Türk Sanatları Bölümü email: renginoyman35@gmail.com (DORCID ID: https://orcid.org/0000-0002-6379-4755

iThenticate" iTu makale bilimsel etik ve kurallara uygun hazırlanmış ve intihal incelemesinden geçirilmiştir.

Atıf (APA 6)/To cite this article

Demiral, B., \& Oyman, N. R. (2020). Isparta Müzesi’ndeki Yalvaç yöresi düz dokuma torba örnekleri. Atatürk Üniversitesi Güzel Sanatlar Enstitüsü Dergisi, 26(44), 161-169. doi: https://doi.org/10.35247/ataunigsed.652384

Makale Gönderim Tarihi/Received: 03/12/2019

Makale Kabul Tarihi/Accepted: 17/03/2020

Makale Yayın Tarihi/Published: 19/03/2020

Research Article / Araştırma Makalesi

Öz

Dokumalar konar-göçer yaşamının önemli üretimlerindendir. Bu dokuma örneklerinden Kirkitli Düz dokumalar yer yaygısı ve süsleme amaçlı kullanılmasının yanında, taşımada da kullanılmaktadır. Cuval, heybe gibi torba da taşıma amacıyla kullanılan kirkitli dokumalardandır. Torba: küçük boyutlarda taşımada ve çadır içerisinde süs olarak kullanılan bir eşyadır. Bu arastırmada Yalvaç yöresine ait olan ve Isparta Müzesi'nde bulunan 10 adet torba, dokuma tekniği, hammadde, renk, motif ve kompozisyon yönlerinden incelenmiștir. Torbalar genellikle yün malzeme ile cicim ve zili tekniklerinde dokunmuşlardır. Torbaların kompozisyonlarında beyaz, bordo, kırmızı, mavi, mor, sarı, siyah, turuncu, yeşil renklerin ve haytağacı, büyük duma, göz, yıldız, pıtrak, suyolu, çengel, muska, kurtizi, saçbağı motiflerinin kullanıldığı görülmüştür. Torbaların kompozisyonları genellikle, orta zeminde bir motifin sonsuz tekrarı ve zeminin etrafını saran bordürden oluşmaktadır.

Anahtar kelimeler: Düz Dokuma, Torba, Yalvaç, Isparta Müzesi

\begin{abstract}
Weavings are important productions of nomadic life. One of these weaving samples, Kirkitli flat weavings are used both for floor covering and decorative purposes and also used for transportation. Carrierbag such as sacks and saddlebags are also used for carrying purposes. Carrierbag: It is an item used for carrying in small dimensions and as an ornament in a tent. In this research, 10 carrierbags belonging to Yalvac region and found in Isparta Museum were examined in terms of weaving technique, raw material, color, motif and composition. The carrierbags are mostly woven with wool material and zıli, cıcım weaving techniques. It was observed that white, burgundy, red, blue, purple, yellow, black, orange, green colors and tree of life, greatduma, aye, star, burdock, running water, hook, amulet, wolf's track, and hair band motifs were used in the compositions of the carrierbags. The compositions of the carrierbags usually consist of an endless repetition of a motif on the middle floor and a border that surrounds the midle floor.
\end{abstract}

Keywords: Plain Weaving, Carrierbag, Yalvac, Isparta Museum

\section{Giriş}

Tarihi Orta Asya'ya kadar uzanan Geleneksel Türk el sanatları, göçebe (yörük) yaşamının vazgeçilmez unsurlarındandır. 1071 Malazgirt Savaşı'ndan sonra Türkler, zengin sanat ve kültürlerini de Anadolu'ya getirmişlerdir. Isparta bölgesine yerleşen Türk boyları da bu el sanatı ürünlerini buraya taşımıştır. Bu bölgede yaşatmakta oldukları Türk el sanatı ürünleri bulunmaktadır.

Akdeniz Bölgesi'nin batısında, Göller Bölgesi'nde yer alan Isparta'nın yüz ölçümü 8933 km2'dir. Kuzey doğuda ve doğuda Sultan Dağları, Beyşehir Gölü ve Dedegöl Dağları'nın uzantıları, güneyde Antalya Havzası'nın yüksek kesimleri, batıda ve güneybatıda Karakuş Dağları, Söğüt Dağları, Burdur Gölü Ağlasun ve Bucak yaylaları ile sınırlıdır (Anonim, 1996, s. 7-8). Isparta'da Avşar, Bayat, Beydili, Büydüz, Çavındır, Döğer, Eğmür, Iğdır, Kayı, Kargın, Karaevli, Kınık, Peçenek, Salur, Yazır, Yüreğir gibi oymaklar yaşamaktadır (Koç, 1983, s. 14).

Geleneksel el sanatlarından halıcılık, kilimcilik, oya ve nakış işlemeleri yörede yaygındır. Dericilik, Keçecilik, Saraçlık, Semercilik ve Nalbantlık gibi el sanatlarının günümüzde sadece Yalvaç ilçesinde, Bıçakçılığın ise yalnızca İl merkezi ile Uluborlu ilçesinde yapıldı̆̆ı görülmektedir. Isparta'da düz dokumaların en yaygın olduğu yerler Yörük köyleridir. Buralarda heybe, çanta (torba) ve çuvallar da dokunduğu görülür. Isparta'da El sanatlarından yün ve kıldan imal edilen çuval, heybe, aba, çadır, kilim ve çulha gibi dokumalar zamanın gelişen ihtiyaçlarına ayak uyduramayarak ortadan kaybolmaya yüz tutmuşlardır (“Isparta”, t.y.). Isparta Müzesi'nde bu el sanatları ürünlerinin bazılarının korunması ve sergilenmesi sağlanmaktadır. 
Isparta'da müzecilik 1933 yılında arkeolojik eserler ve mezar taşlarından oluşan eserlerin halkevinde sergilenmesi ile başlamıştır. 1973 yılında Halil Hamit Paşa Kütüphanesi'nin bir odası müze deposu olarak kullanılması ile müze memurluğu kurulmuştur. Bugünkü müze binası ise $1985^{\circ}$ te ziyarete açılmıştır (Anonim, 1996, s. 21). 1989 y1lında müze binasına arkeoloji salonu eklenmiştir (Gerçek, 1999, s. 470). Arkeoloji, Hazine, Etnografya ve Halı olmak üzere 4 ana bölümden oluşan müzede, 2002 yılı itibarıyla 2557 adet arkeolojik, 1961 adet etnografik, 11971 sikke olmak üzere toplam 16489 adet eser vardır (Dedeoğlu ve diğerleri, 2005, s. 21). El sanatları ürünlerinden olan kirkitli düz dokumalar olarak sınıflandırılan kilim, cicim, zili, sumak teknikli dokumalar müzede sergilenmekte ve depolarda saklanmaktadır. Isparta Müzesi'nde 40 adet düz dokuma torba tespit edilmiştir. Araştırma örneklemine yalvaç yöresine ait olduğu envanter kayıtlarında belirtilen, 10 adet torba dokuma alınmıştır.

Araştırma kapsamında incelenen düz dokuma torbalar, satın alma yoluyla müzeye gelmiş eserlerden oluşmaktadır. İncelenen eserler, Isparta ve Yalvaç ilçelerinden müzeye kazandırıldığı envanter kayıtlarından tespit edilmiştir. Çalışmada düz dokuma torbalarda kullanılan ham madde, dokuma tekniği, renk, motif ve kompozisyon özellikleri, hakkında tespitlerde bulunulmuştur. Geleneksel düz dokuma torbalar, unutulmaya yüz tutmuş durumdadır. Kaybolmakta olan el sanatı örneklerinin derlenmesi, belgelenmesi, daha sonraki çalışmalara kaynak oluşturması ve unutulup yok olmasını engellemek açısından önemlidir.

Torbalar, içerisinde yiyecek ve bazı yörelerde çocuk taşımak, iç çamaşırı koymak, duvar süsü olarak kullanılmak üzere dokunur. Sırtta taşınır. Ancak kullanılmadığı zamanlarda içerisine iç çamaşırı konularak yüksek bir yere asılır. Evin içerisinde üstte kap-kacak, altta ise torbalar dekorasyon için kullanılır. Evdeki küçük aletlerin konulduğu örnekler daha küçük ebatlarda dokunur (Deniz, 2007, s. 1).

Kilim cicim zili, sumak teknikli dokumalar konargöçerlerin kullanım eşyalarıdır. Bu dokumalar nemden çabuk etkilendikleri için uzun süre sağlamlıklarını koruyamadıklarından dolayı çok az örnek günümüze kadar gelebilmiştir. (Aytaç, 2006, s. 91). Torba dokumalarda çuval dokumalarda olduğu gibi malzeme olarak yün, k1l ve pamuk kullanılmaktadır. Yörüklerde Kılı bükme yünü eğirmeden dokumaya kadar gerekli olan araç ve gereçler şunlardır. İpin dokumaya hazırlanmasında Yün tarağı ve kıl tarağı, kirmen ve iğ, çıkrık veya çark kullanılır. Dokuma aleti olarak ise istar ve çarpana kullanılır (Eröz, 1991, s. 174-178).

Eröz (1991, s. 171)'e göre Yörükler, dokumalarında kıl, yün ve pamuğu çeşitli aşamalardan geçirdikten sonra kullanmıştır. Yörükler diğer dokumalarda kullandıkları malzemeleri torba dokumalarda da kullanırlar. Ayrıca kendi giyeceklerini ve kullanım araçlarını, konutlarını bu malzemelerden elde ederler.

Düz dokumalarda kullanılan araçlar, torba dokumada da kullanıldığından düz dokumalarda kullanılan araçlar olan, Yün tarağı, kıl tarağı, kirmen, çıkrık veya çark ve tezgah (ıstar) torba dokumalarda da kullanılmaktadır.

\section{Metaryal ve Yöntem}

Bu araştırmada, Isparta Müzesin'de 40 adet torba olduğu envanter kayıtlarından tespit edilmiştir. İncelenen örneklerden Yalvaç Yöresine ait olduğu müze envanterinde belirtilen, 10 adet cicim ve zili tekniklerinde dokunmuş torba, araştırma kapsamına alınmıştır. Dokumalar öncelikle müze envanteri taranarak tespit edilmiştir. Tespit edilen torba dokumalar gerekli izinler alınarak incelemesi yapılmıştır. Dokumaların fotoğrafları çekilmiş, ebatları, kaliteleri, teknik, hammadde, renk ve kompozisyonları hakındaki bilgiler, müzedeki yerlerinde görsel incelemesi sonucu elde edilmiştir. Bu bilgiler inceleme fişleri ile kayıt altına alınmıştır. Araştırmada örneklerin fotoğrafları, yüzey şemaları ve motiflerinin görsellerine yer verilmiştir.

\section{Isparta Müzesi’de yer alan Yalvaç Yöresi düz dokuma torba örnekleri}

Müzedeki torbalarda atkı yüzlü kilim, cicim, zili tekniklerinden biri veya bir kaçı bir arada kullanılmıştır. Genel olarak dokumaların hepsinde zili ve cicim tekniğinin ağırlıklı olarak kullanıldığı görülmektedir. Torba dokumalarda uygulanan motif ve kompozisyonlar, araştırma konusu örnekler ve ulaşılabilen diğer yayınlardaki görseller üzerinden yapılmaya çalışılmıştır. Torba dokumalarda bu çalışmada yer verilen motif ve kompozisyon sınıflandırmaları dışında da örneklere rastlanabilir.

Anadolu dokumaları, konar-göçer yaşamın izlerini devam ettirmektedir. Dokumalarda kullanılan motifler ve isimleri dokundukları bölgenin sosyal yapısına göre değerlendirilmelidir (Durul, 1982, s. 26-27). Anadolu dokumalarının en güzel örneklerini Yörük, Türkmen ve Avşarlar vermiştir. Türkmen, Yörük dokumalarındaki desen ve motifler görenek halinde devam ettirilmesinin yanında, dokuyucuların yenilik aradığı dokuma örnekleri de görülmektedir. Ancak aşiretin özel işaretleri (im) ile uğurlu veya uğursuz sayılan motiflerinin yerinde kullanmasına özel dikkat gösterilmiştir (Durul, 1956, s. 92). Isparta Müzesi'ndeki düz dokuma torbalarda, hayatağacı, saçbağı, büyük duma, kurtizi, göz, çengel, pıtrak, suyolu, yıldız ve muska motifleri dokunduğu görülmektedir (Görsel 1).

Torbalarda görülen motiflerden Hayat ağacı motifi (Görsel 1a) sürekli gelişim, sürekli değişim ve gelişim içinde yaşayan evreni simgeler. Toprağın altında kalan kökleriyle yer altını, alt dalları ve gövdesiyle yeryüzünü, ışı̆̆a yükselen üst dallarıyla cenneti anlatır. Yeryüzü ve cennet arasındaki iletişimi sağladığına inanılır. Anadolu 
motiflerinde hayat ağacı "can ağacı" olarak da nitelendirilir; ölümsüzlüğün sembolüdür. Özellikle selvi ağac1 ölümsüzlüğü simgeler (Erbek, 2002, s. 166-168). Bu motif, Şamanizm kökenlidir. Orta Asya Şaman kaynaklarına göre hayat ağacı, dünyanın merkezi olarak kabul edilmektedir. Şamanın yeraltı veya gökyüzü seyahatinde merdiven işlevi görür (Erbek, 2002, s. 166-168).

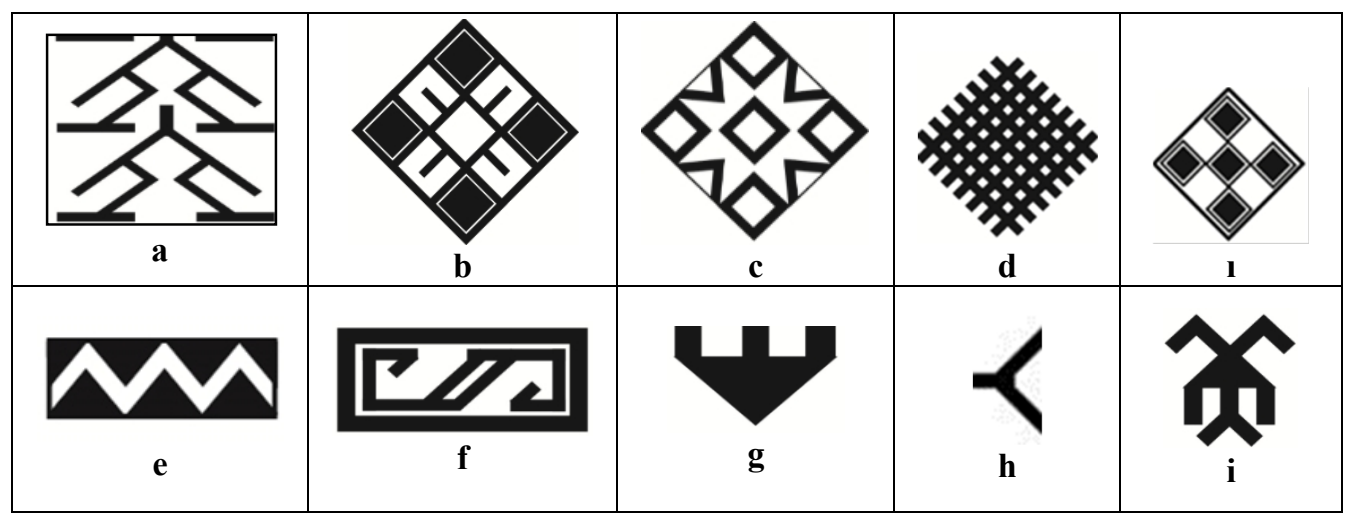

Görsel 1. Düz dokuma torbalarda görülen motifler: a. Haytağacı motifi; b. Büyük Duma motifi; c. Yıldız motifi; d. Pıtrak motifi; e. Suyolu motifi; f. Çengel motifi; g. Muska motifi; h. Kurtizi motifi; 1. Göz motifi; i. Saçbağı motifi

Torbalarda karşımıza çıkan Diğer bir motif ise göz motifidir. En basit göz formu, geometrik üçgen motifidir. Anadolu dokumalarında göz motifi üçgen olmasının yanında, kare, eşkenar dörtgen, dikdörtgen, haç olarak da uygulanmaktadır (Görsel 1i). En çok görülen göz motifi dörde bölünmüş eşkenar dörtgendir (Erbek, 2002, s. 128). Nazar denen zararlı ve öldürücü bakışların suçlusu göze karşı tedbir olan yine gözün kendidir (Ateş, 1992, s. 43).

Çengel motifi Anadolu dokumalarında özellikle halı ve kilimlerde görülen bir motiftir (Görsel 1f). Kötü göze karş1 kullanılan motif aynı zamanda erkek ile kadın arasında birleştirici olarak görülmektedir. Oğuz boylarından Bayındır aşiretinin imi olarak da kullanılmaktadır (Ateş, 1992, s. 28).

Pıtrak, dikenleriyle insanların ve hayvanların tüylerine yapışan bir bitkidir. Anadolu El Sanatlarında kullanılan pıtrak motifi, bu bitkinin stilize edilmiş şeklidir (Görsel 1d). Anadolu insanı, pıtrağı nazarlık motifi olarak kullanmaktadır. Pıtrak, bereketli olmaları için un çuvallarında, tandır örtülerinde, ekmek üstüne kapanan cicim dokumalarında görülmektedir. Mersin Yörük dokumalarında Muğla, Bodrum, Adana, Karatepe kilimlerinde, Denizli, Afyon Türkmen dokumalarında çuval, heybe, at örtüsü, çocuk beşiği gibi eşyalarda da pıtrak motifine s1kça görülmektedir (Erbek, 2002, s. 108).

Suyolu motifi, ismini Ege Denizi'ne dökülen Menderes Nehri’nden almıştır. Yeniden doğuşun, bedensel ve ruhsal temizliğin, yaşamın akışkanlığının ve sürekliliğin, bereket, soyluluk, bilgelik, saflık ve erdemin sembolü olan suyolu motifi, zikzak şeklinde dokumalara yansımıştır (Görse le). Anadolu dokumalarında sıklıkla kullanılmıştır (Erbek, 2002, s. 102-104).

Yıldız motifinin en basit formu iç içe geçmiş iki üçgenden oluşmaktadır. Bu form kare ve haç motifi ile birlikte anlamsal bir bütünlük oluşturarak, evreni simgelemektedir; yani dört dünya ve dört gök bölgesinin simgesel anlatımıdır. Ayrıca beș köșeli yıldız, bir açıdan yedi sayısının sembolizmini paylaşır, bir açıdan da küresel müziğin evrensel uyumunu, gökkuşağının renklerini, gezegenlerle ilgili yedi alanı ve bireysel bütünlüğü sembolize eder (Görsel 1c). Altı köşeli yıldızlar ise zıtlıkları, evliliği ve evrenin yalnızlığını ve karmaşıklığını ifade edecek şekilde dokumalarda yer almaktadır (Erbek, 2002, s. 102-104).

Muska ve nazarlık motifleri, belli özelliklere sahip kimselerde bulunduğuna inanılan insanlara, evcil hayvanlara, eve, mala, mülke hatta cansız nesnelere zarar veren, bakışlardan kaynaklanan ve öldürücü bir etkisi olduğuna inanılan, nazara karşı kullanılan motiflerdendir. Bu nedenle rengi ve biçimi gözü andıran her nesne, nazarı uzaklaştırıcı motif olarak dokumalarda yer almıştır (Görsel 1g). Muska motifi genellikle eşkenar üçgenle sembolize edilmektedir (Erbek, 2002, s. 120).

Araştırma konusu torbalar genellikle kare kompozisyonludur. Torbaların zemini, sonsuz kaydırma ilkesi ile çeşitli motiflerin tekrar edilmesi ile oluşturulmuştur. Zeminin alt, üst ve sağ solunu bordürler çevrelemektedir. Düz dokuma torbalarda kompozisyonlar, zeminin baklava dilimlerine ayrılmasıyla, aynı motifin büyüyerek zemini kaplamasıyla, aynı motif veya motif gurubunun üst üste sonsuz tekrarlanmasıyla oluşturulmuştur. Bu kompozisyon örnekleri Görsel 2'de görülmektedir. 


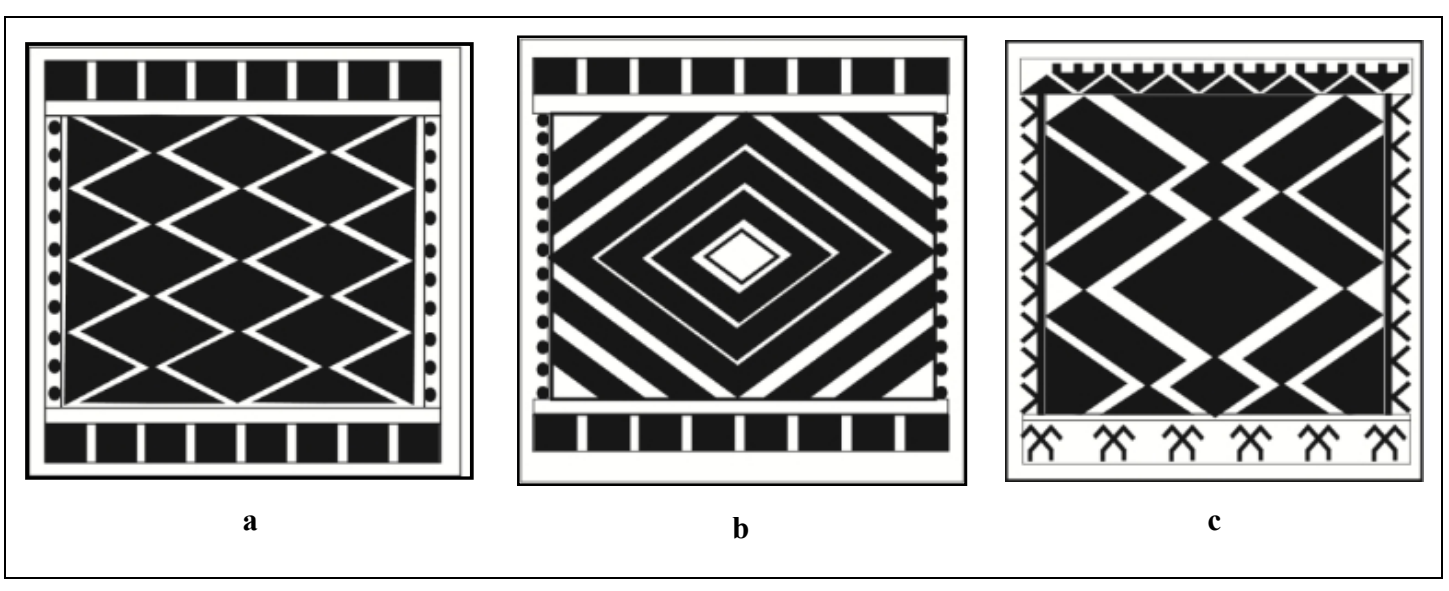

Görsel 2. Düz dokuma torbalarda görülen kompozisyonlar: a. Zeminin baklava dilimlerine ayrılmasıyla oluşturulmuş kompozisyon; b. Aynı motifin büyüyerek zemini kapladı̆̆ı kompozisyon; c. Aynı motif veya motif gurubunun üst üste sonsuz tekrarı ile oluşturulan kompozisyon

Isparta müzesindeki torbalarda beyaz, bordo, kırmızı, mavi, mor, sarı, siyah, turuncu ve yeşil renkler kullanılmıștır. 8 adet cicim ve zili tekniği ile dokunmuş torbada beyaz, 2 adet torbada ise siyah renkli motif ipleri dişında, çözgü ve atkı olarak kullanıldıkları tespit edilmiştir. Diğer renklerin ise motiflerde kullanıldığ 1 görülmüştür. Müze envanterinde Yalvaç yöresine ait olduğu belirtilen torbaların aynı yöreye ait oldukları, benzer motif ve kompozisyonlarının yanında benzer renklerin kullanılmış olmasından da anlaşılabilmektedir.

Isparta Müzesi'nde 5-1-88 envanter numarası ile kayıtlı olan 45x41 cm ölçülerinde zili ve cicim tekniğinde dokunmuş torba Görsel 3a'da görülmektedir.

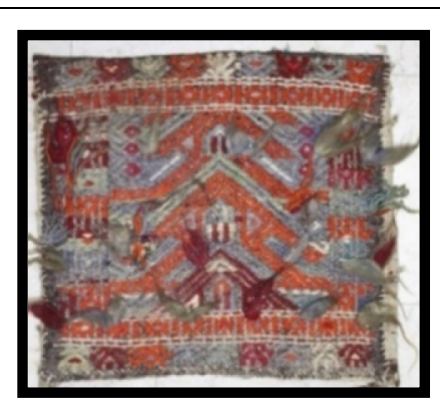

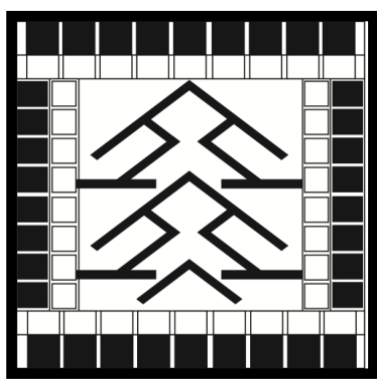

b

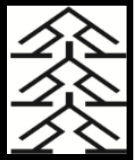

c

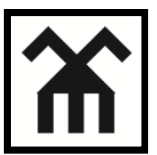

d

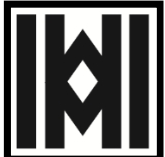

Görsel 3. a. Torba; b. Yüzey şeması; c. Hayatağacı motifi; d. Saçbağı motifi; e. Göz motifi

Görsel 3a’da yüzey şeması görülen torbada atk1, çözgü ve motif ipi olarak yün kullanılmıştır. Dokumada Siyah, beyaz, kırmızı ve turuncu renkler görülmektedir. Bu örneğin zemininde hayatağacı motifi (Görsel 3c) sonsuz tekrar prensibine göre yerleştirilmiştir. Dokumanın bordürünün alt ve üst kısmında yörede saçbağı olarak bilinen motif (Görsel 3d) görülmektedir. Sağ ve sol bordürlerde göz veya muska motifi olarak yorumlanabilecek motif (Görsel 3e) üst üste yerleştirilmiştir. Dokumanın arka yüzü, düz bezayağı tekniğiyle motifsiz olarak dokunmuştur.

Görsel 4a'daki 5-2-88 envanter numaralı torba, 44x44 cm ölçülerinde zili ve cicim tekniğinde dokunmuştur.

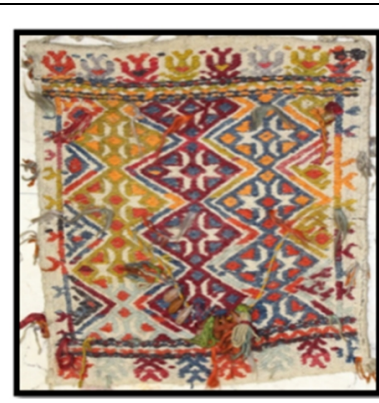

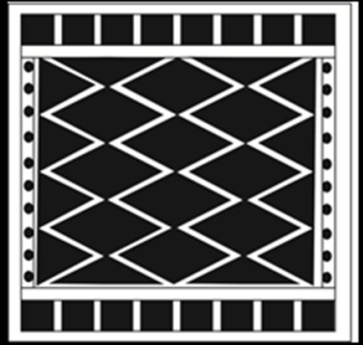

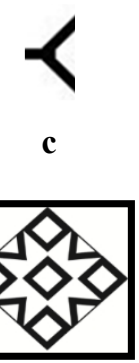

d

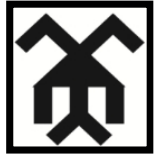

e

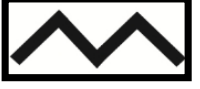

Görsel 4. a. Torba; b. Yüzey şeması; c. Kurizi motifi; d.Yıldız motifi; e. Saçbağı motifi; f. Suyolu motifi 
Atkı, çözgü ve motif ipi olarak yün kullanılmıştır. Dokumada yeşil, mavi, turuncu, siyah, kırmızı ve bordo renkler görülmektedir. Zemininde yıldız motifi (Görel 4d) baklava dilimi bölünmüş alanların içerisine yerleştirilmiştir. Bordürün alt ve üst kısmında saçbağı (Görsel 4e) ve suyolu motifleri (Görel 4f) görülmektedir. Bordürün Sağ ve sol kısımlarında kurtizi motifi (görsel 4c) vardır. Dokumanın arka yüzü, düz bezayağı tekniğiyle motifsiz olarak dokunmuştur.

Görsel 5a'da 5-3-88 envanter numaralı torba $43 \times 44 \mathrm{~cm}$ ölçülerinde zili ve cicim tekniğinde dokunmuş torba görülmektedir.

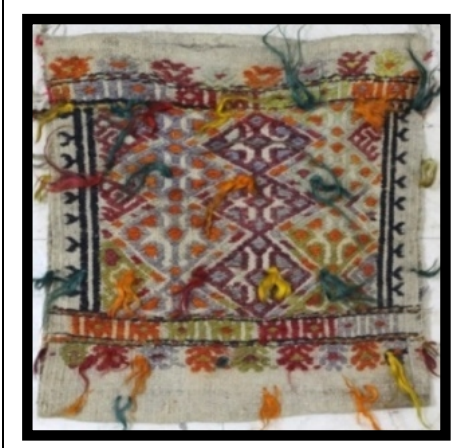

a

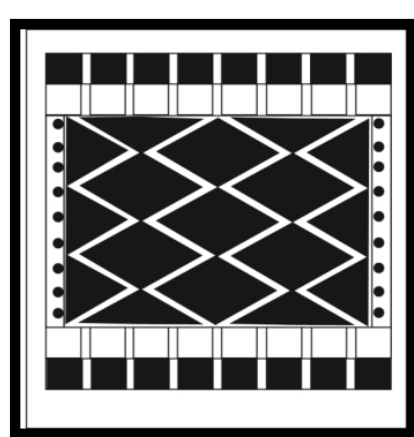

b

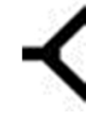

c

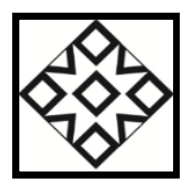

d

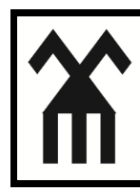

e

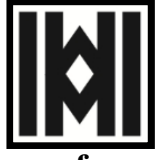

f

Görsel 5. a. Torba; b. Yüzey şeması; c. Kurtizi motifi; d. Yıldız motifi; e. Saçbağı motifi f. Göz motifi

Görsel 5b'de yüzey şeması görülen torbada atkı, çözgü ve motif ipi olarak yün kullanılmıştır. Dokumada yeşil, kırmızı, turuncu, mavi, siyah, bordo renkler görülmektedir. Zemininde yıldız motifi (Görsel 5d) baklava dilimi bölünmüş ve sonsuz tekrar prensibine göre yerleştirilmiştir. Dokumanın bordürünün alt ve üstünde saç bağı (Şekil 5e) ve göz motiflerinden (Görsel 5f) oluşan iki bant üst üste yerleştirilmiştir. Bordürün Sağ ve solunda kurtizi motifi (Görsel 5c) vardır. Dokumanın arka yüzü, düz bezayağı tekniğiyle motifsiz olarak dokunmuştur.

5-4-88 envanter numaralı, Yalvaç yöresine ait diğer bir torba (Görsel 6a) 41x41 cm ölçülerinde zili ve cicim tekniğinde dokunmuştur.

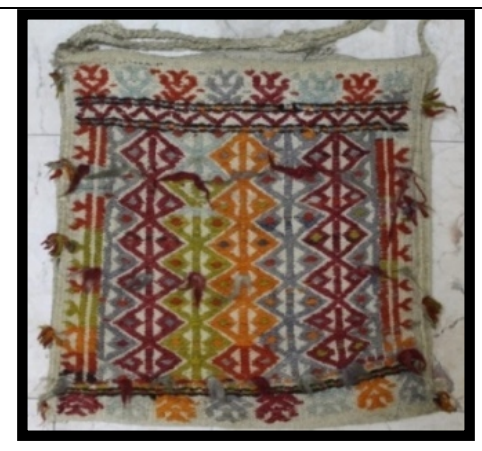

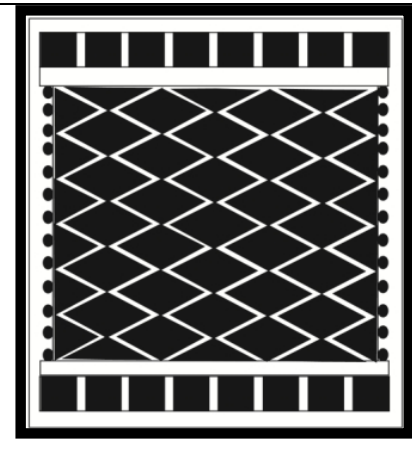

b
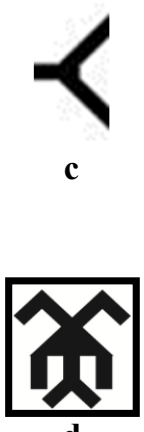

d

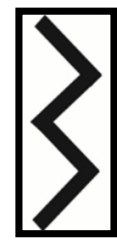

e

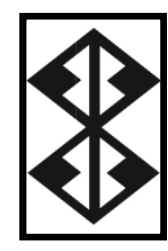

f

Görsel 6. a. Torba; b. Yüzey şeması; c. Kurtizi motifi; d. Saçbağı motifi; e. Suyolu motifi; f. Göz motifi

Torbada Atkı, çözgü ve motif ipi olarak yün kullanılmıştır. Zemininde baklava dilimi bölünmüş alanlara, göz motifi (Görsel 6f) sonsuz tekrar prensibine göre yerleştirilmiştir. Dokumanın bordürünün alt ve üst kısmında saçbağı motifi (Görsel 6d) vardır. Ayrıca bordürün üst kısmının altındaki bantta suyolu motifi (Görsel 6e) görülmektedir. Bordürün Sağ ve solunda kurtizi motifi (Görel 6c) görülmektedir. Sarı, yeşil, bordo, kırmızı, mavi, beyaz ve siyah dokumada kullanılan renklerdir. Dokumanın arka yüzü, düz bezayağı tekniğiyle motifsiz olarak dokunmuştur.

5-5-88 envanter numaralı torba Görsel 7a'da görülmektedir. 42x43 cm ölçülerindeki torbanın zemini zili, bordürleri ise cicim tekniğinde dokunmuştur. Atkı, çözgü ve motif ipi olarak yün kullanılmıştır. 


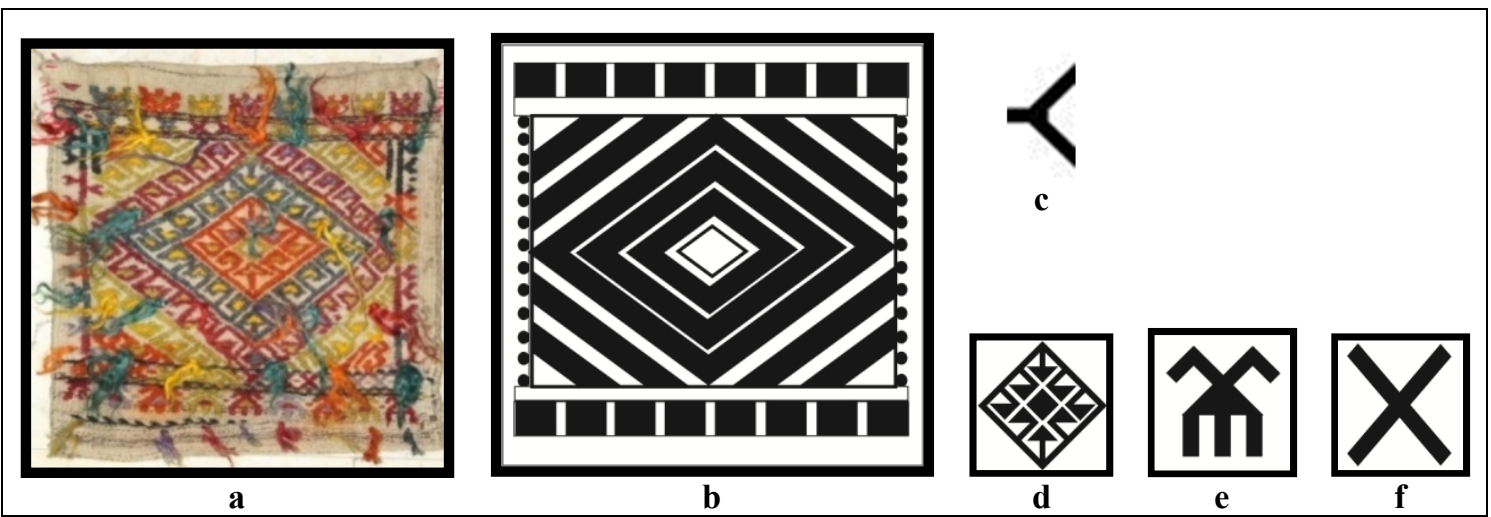

Görsel 7. a. Torba; b. Yüzey şeması; c. Kurtizi motifi; d. Akrep motifi; e.Saçbağı motifi; f. Çarpı motifi

Zemininde akrep motifi (Görsel 7d) görülmektedir. Dokumanın bordürünün alt ve üstündeki iki bantta saçbağ1 (Görsel 7e) ve çarpı motifi (Görsel 7f) bulunmaktadır. Bordürün Sağ ve sol kısmında kurizi motifi (Görsel7c) vardır. Sarı, yeşil, kırmızı, mavi, turuncu dokumada görülen renklerdir. Dokumanın arka yüzü, düz bezayağı tekniğiyle motifsiz olarak dokunmuştur.

5-7-88 envanter numaralı, Ön yüzü (Görsel 8a) ve arka yüzü (Görsel 8c) motifli olan kapaklı torba, 35x36 cm ölçülerinde zili ve cicim tekniğinde dokunmuştur.
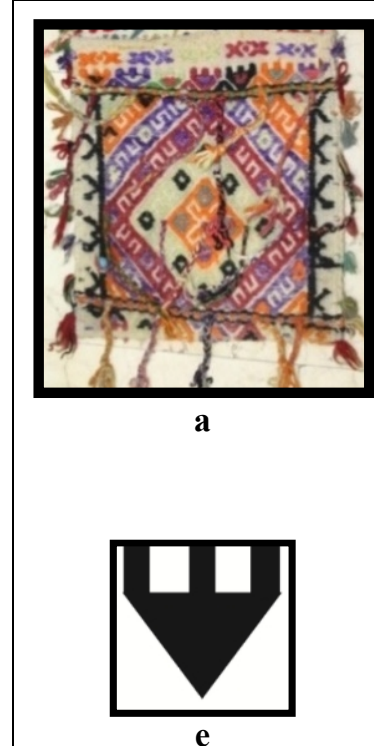

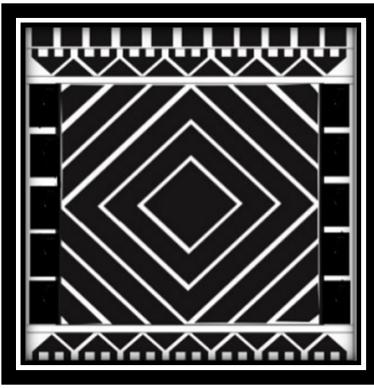

b

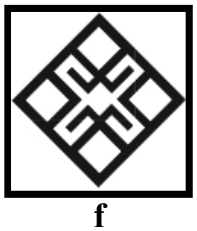

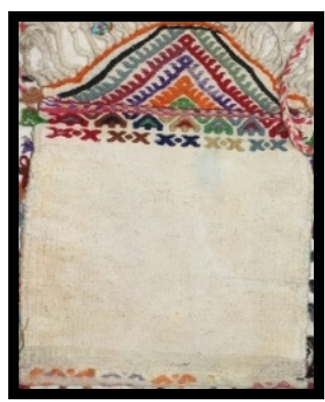

c

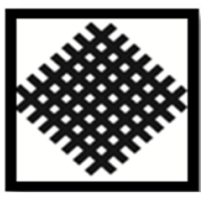

g

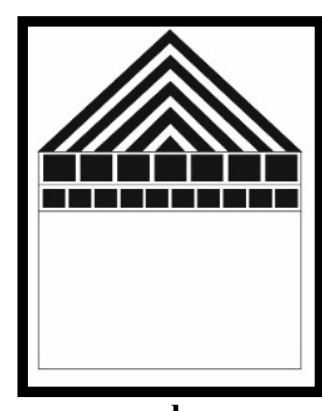

d

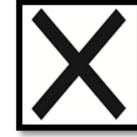

h

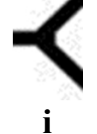

Görsel 8. a. Torba ön yüzü; b. Ön yüz yüzey şeması; c. Torba arka yüzü; d. Arka yüz yüzey şeması; e. Muska motifi; f. Büyük Duma motifi; g. Pıtrak motifi; h. Çarpı motifi; i. Kurtizi motifi

Atkı, çözgü ve motif ipi olarak yün kullanılmış olan torbanın zemininin merkezinde koçboynuzu motifi (Görsel 8f) vardır. Bu motifin etrafında yörede "büyük duma" (Görsel 1b) olarak adlandırılan (İ. Akçay, sözlü görüşme, 25.10.2019) motif görülmektedir. Dokumanın bordürünün alt ve üstündeki iki bantta muska (Görsel 8e) ve çarp1 motifi (Görsel 8h) bulunmaktadır. Bordürün sağ ve solunda kurtizi motifi (Görsel 8i) vardır. Dokumada mor, yeşil, kırmızı, beyaz ve siyah renkler görülmektedir. Dokumanın arka yüzü (Görsel 8c) düz bezayağı ve cicim tekniği ile dokunmuştur. Torbanın kapak kısmında pıtrak motifi (Görsel 8g) vardır. Kapak kısmı dışında arka yüzde ön yüzdeki çarpı ve muska motifleri iki bant halinde tekrar etmektedir (Görsel 8e), (Görsel 8h).

Isparta Müzesi'nde 5-8-88 envanter numarası ile kayıtlı, 38x41 cm ölçülerinde cicim tekniğinde dokunmuş torba Görsel 9a'da görülmektedir. 


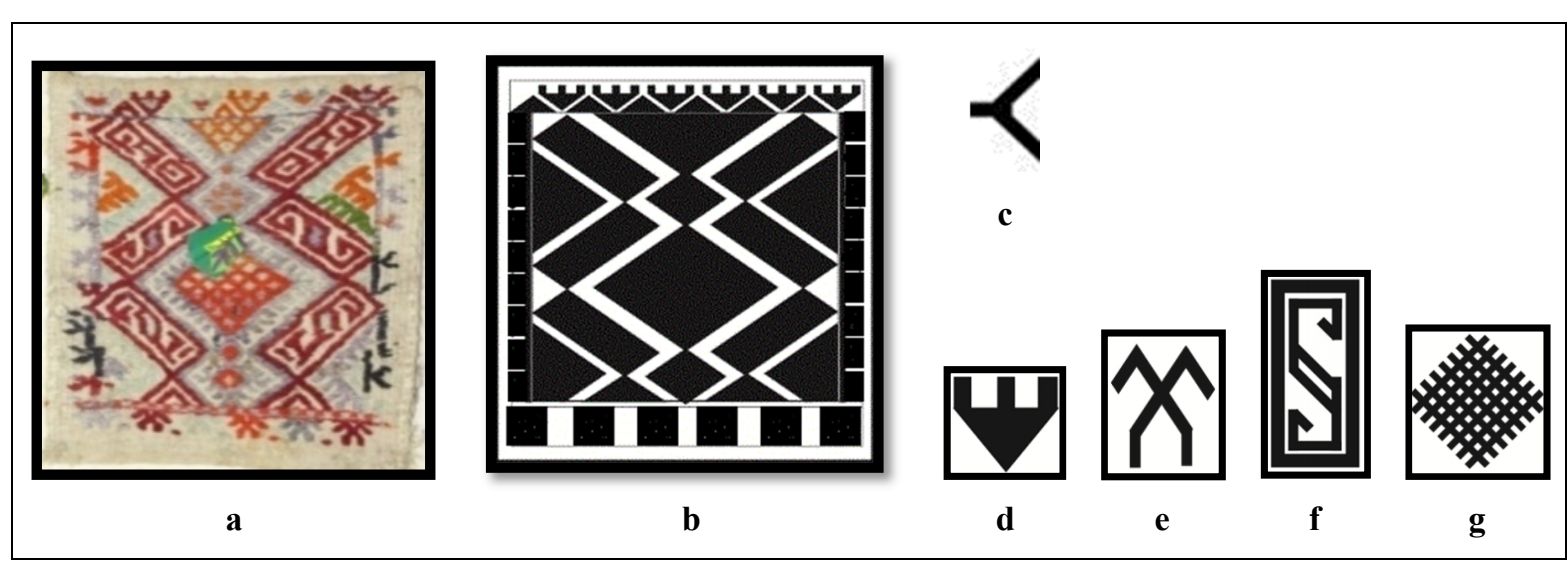

Görsel 9. a. Torba; b. Yüzey şeması; c. Kurtizi motifi; d. Muska motifi; e. Saçbağı motifi; f. Çengel motifi; g. P1trak motifi

Atkı, çözgü ve motif ipi olarak yün kullanılmış olan torbanın zemininde, pıtrak (Görsel 9g) ve çevresininde çengel motifleri (Görsel 9f) görülmektedir. Dokumanın bordürünün alt kısmında saçbağı motifi (Görsel 9e) vardır. Bordürün üst kısmında ise muska motifi (Görsel 9d) bulunmaktadır. Bordürün sağ ve soluna kurtizi motifi (Görsel 9c) yerleştirilmiştir. Dokumadaki renkler mor, yeşil, kırmızı, turuncu ve siyahtır. Dokumanın arka yüzü, düz bezayağı tekniğiyle motifsiz olarak dokunmuştur.

Yalvaç yöresine ait 5-9-88 envanter numaralı torba Görsel 10a’da görülmektedir.

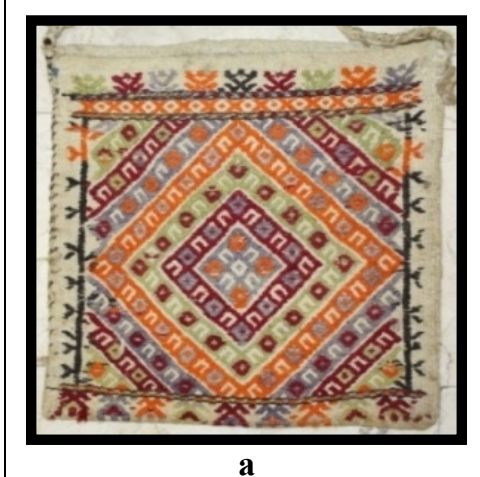

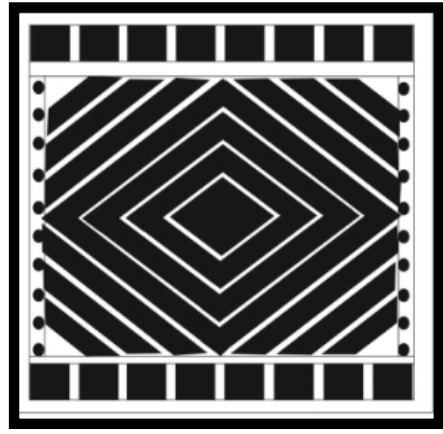

b

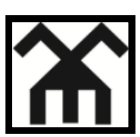

c

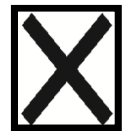

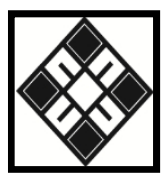

e

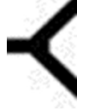

Görsel 10. a. Torba; b. Yüzey şeması; c. Saçbağı motifi; d. Çarp1 motifi; e. Büyük duma motifi; f. Kurtizi motifi

$42 \times 43 \mathrm{~cm}$ ölçülerinde cicim ve zili tekniğinde dokunmuş olan torbada Atkı, çözgü ve motif ipi olarak yün kullanılmıştır. Zemininde yörede büyük duma olarak isimlendirilen (Görsel 10e) motif(İ. Akçay, sözlü görüşme, 25.10.2019) görülmektedir. Dokumanın bordürünün altında saçbağı motifi (Görsel 10c) vardır. Bordürün üst kısmında ise bantlar halinde, saçbağı ve çarpı motifi (Görsel 10d) bulunmaktadır. Bordürün sağ ve solunda kurtizi motifi (Görsel 10f) yerleştirilmiştir. Dokumada, yeşil, kırmızı, mavi, turuncu, siyah ve beyaz renkler görülmektedir. Dokumanın arka yüzü, düz bezayağı tekniğiyle motifsiz olarak dokunmuştur.

Isparta müzesi'de 5-10-88 envanter numarası ile kayıtlı torba Görsel 11a'da görülmektedir.

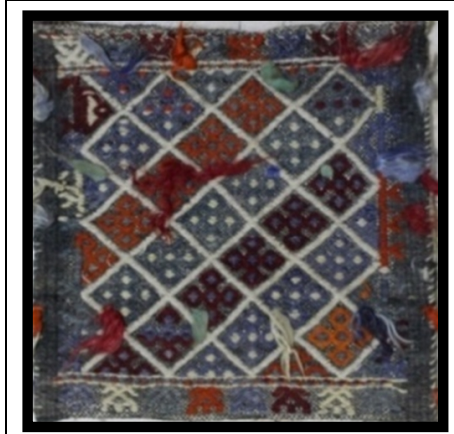

$\mathbf{a}$

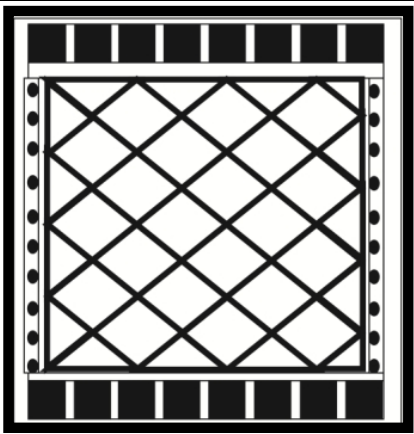

b
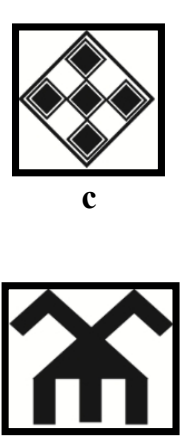

d

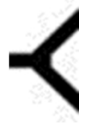

Görsel 11. a. Torba; b. Yüzey şeması; c. Göz motifi; d. Saçbağı motifi; e. Kurtizi motifi 
40x40 cm ölçülerinde cicim ve zili tekniğinde dokunmuş torbada, atkı ve motif ipi olarak yün, çözgüde ise kıl kullanılmıştır. Zemininde göz motifi (Görsel 11c) baklava dilimlerine bölünmüş alanların içerisine sonsuzlık prensibine göre yerleştirilmiştir. Dokumanın bordürünün alt e ve üst kısmında saçbağı motifi (Görsel 11d) vardır. Bordürün să̆ ve sol kısmında ise kurtizi motifi (Görsel 11 e) görülmektedir. Dokumada, bordo, turuncu, mavi, gri, siyah ve beyaz renkler görülmektedir. Torbanın arka yüzü, düz bezayağı tekniğiyle motifsiz olarak dokunmuştur.

5-11-88 envanter numaralı Yalvaç yöresine ait torba Görsel 12a’da görülmektedir.

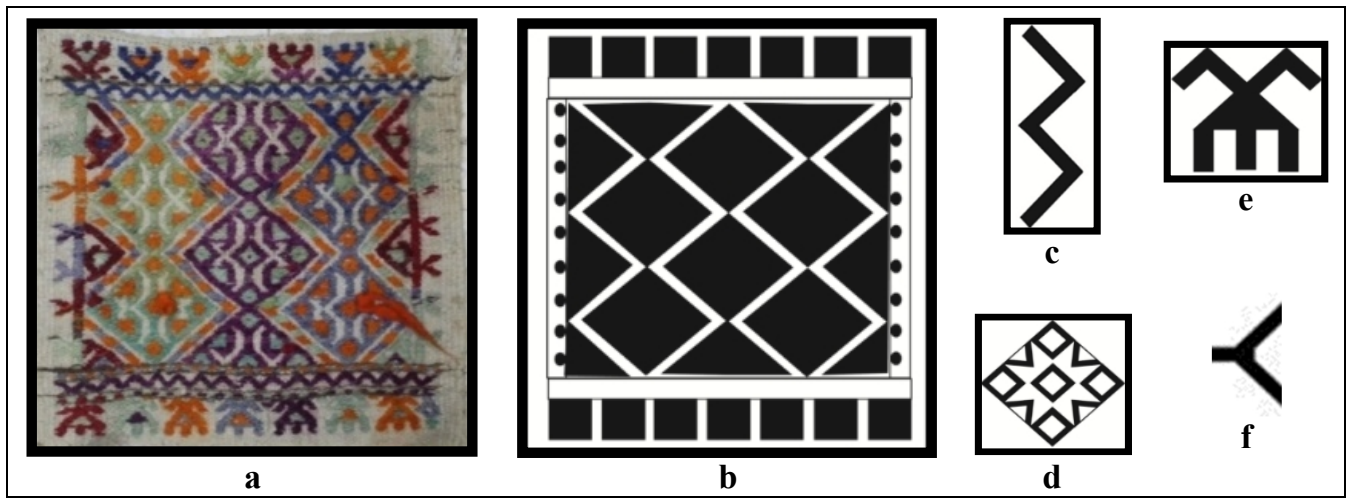

Görsel 12. a. Torba; b. Yüzey şeması; c. Suyolu motif; d. Yıldız motifi; e. Saçbağı motifi; f. Kurtizi motifi

Torba, 43x40 cm ölçülerinde cicim ve zili tekniğinde dokunmuştur. Atk1, çözgü ve motif ipi olarak yün kullanılmıştır. Zemininde yıldız motifi (Görsel 12d) baklava dilimlerine bölünmüş alanların içerisine yerleştirilmiştir. Torbanın bordürünün alt ve üst kısmında saçbağı motifi (Görsel 12e) ve suyolu motifi (Görsel 12c) bantlar halinde görülmektedir. Bordürün sağ ve sol kısmında kurtizi motifi (Görsel 12f) vardır. Dokumada, bordo, yeşil, mor, mavi, turuncu ve beyaz renkler görülmektedir. Torbanın arka yüzü, düz bezayağı tekniğiyle motifsiz olarak dokunmuştur

\section{Sonuç}

İncelenen torbaların envanter kayıtlarında, satın alınma yoluyla müzeye kazandırıldı̆̆ı, Yalvaç yöresinde dokunduğu ve Cumhuriyet dönemine ait olduğu belirtilmektedir. Isparta Müzesi envanterine kayıtlı düz dokuma torbaların Yalvaç yöresine ait olduğu renk, motif ve kompozisyon özelliklerinden anlaşılmaktadır. Torbalarda turuncu ve kırmızı en fazla kullanılan renktir. Bunlar dışında kullanılan renkler yeşil, mavi, sarı, siyah, gri ve bordodur. Örneklerde genellikle ikiden fazla renk bir arada kullanılmıştır. Atkı ve çözgü renklerinde ise genellikle beyaz renk kullanılmıştır. İki örneğin atkılarında siyah renk kullanılmıştır. Torbaların hepsinde çözgü ipliklerinde yün kullanılmıştır. 2 örneğin atkı ipliklerinde kıl kullanılmış diğer örneklerde yün kullanılmıştır. Torbalarda en fazla görülen motif kurtizi motifidir. Yıldız ve göz motifi genellikle zeminde görülmektedir. Suyolu motifi de bordürlerde kullanılmıştır. Bir örnekte hayatağacı motifi kullanılmıştır. Müzede bulunan torbalarda genellikle kare kompozisyon içerisinde zemin, sonsuz kaydırma ilkesi ile çeşitli motiflerin tekrarı ile oluşturulmuş. Zeminin alt ve üst kısımlarında bantlar içerisine yerleştirilen motifler ile bordürler oluşturulmuştur. Alt ve üst bordür dışında zeminin sağ ve solunda da dikey bantlar bulunmaktadır. Bir diğer kompozisyon ise zemini merkezden dişa doğru aynı motifin daha büyük tekrarları ile oluşturulan kompozisyondur. Bu kompozisyonda da diğer kompozisyonlarda olduğu gibi bordürler aynıdır. Bir diğer kompozisyonda ise aynı motif veya motif gurubu üst üste sonsuz tekrarı ile oluşturulmaktadır.

Araştırma konusu düz dokuma torbalar, Isparta Müzesi’nde teşhirde sergilenmeyip depoda saklanmaktadır. Bu dokumaların teşhirde sergilenmesi ile ziyaretçilerin geleneksel sanat ürünlerinden olan torbaları görmeleri sağlanmalıdır. Isparta Müzesi'nde bulunan Düz dokuma torba örneklerinin, envanter kayıtlarında kalite, dokuma teknikleri, renk, motif ve kompozisyon özellikleri hakkında yeterince bilgi verilmediği tespit edilmiştir. Bu bilgi eksiklerinin uzman kişiler tarafindan giderilmesi gerekmektedir. Böylece gelecek kuşaklara ve başka çalışmalar yapacaklara bu dokumalar hakkındaki bilgilerin doğru aktarılması sağlanacaktır. Ayrıca bu envanter bilgilerinin doğru bir şekilde bilgisayar ortamına aktarılması ile yapılacak çalışmaların daha kolay ve verimli olması sağlanabilir. 


\section{Kaynakça}

Anonim. (1996). Isparta İl Yıllı̆̆ı. Isparta

Ateş, M. (1992). Türk halıları, motiflerin-sembollerin dili. Nevşehir: Ema Kâğıtçılık Matbaacılık.

Aytaç, Ç. (1997). El Dokumacılığı. İstanbul: Milli Eğitim Basımevi.

Aytaç, A. (2006). Geleneksel Türk el dokumacılı̆̆ı sanatı. Konya: Anka Basım Yayın.

Dedeoğlu, J., Süzen, B., İşçi, N., Akaslan, M., Cüceren, İ., İnci, F., \& Demirci, D. (2005). Isparta müzesi. Ankara: Kültür ve Turizm Bakanlığı Kültür Varlıkları ve Müzeler Genel Müdürlüğü Yayınları.

Deniz, B. (2007). Tekstil ürünlerini saklamada kullanılan halı ve düz dokumalar. Atatürk Üniversitesi Güzel Sanatlar Fakültesi Sanat Dergisi, 12, 1-13. Erişim adresi: https://dergipark.org.tr/tr/download/articlefile/28925

Durul, Y. (1956). Halı ve kilimlerde kız motifleri. Türk Etnografya Dergisi, Sayı. 1. Ankara.

Durul, Y. (1982). Kilim motifleri üzerine bir araştırma. Sanat Dünyamız, Sayı. 24. İstanbul.

Erbek, M. (2002). Çatalhöyük’ten günümüze Anadolu motifleri. Ankara: Dösim Yayınları.

Eröz, M. (1991). Yörükler. İstanbul: Türk Dünyası Araştırmaları Vakfı.

Gerçek, F. (1999). Türk müzeciliği. Ankara: Kültür Bakanlı̆̆ı Yayınları.

Isparta İl Kültür ve Turizm Müdürlüğü. (t.y.). Erişim adresi: https://isparta.ktb.gov.tr/TR-71001/geleneksel-elsanatlari.html

Koç, M. (1983). Baris-Hamit-Hamitabat tüm yönleriyle Isparta. Isparta: Türk Köyü Yayınları.

\section{Görüşme}

İmdat Akçay. (2019). Sözlü Görüşme, Yalvaç Yarıkkaya Köyü (25/10/2019).

\section{Görsel Kaynakçası}

Görsellerin tamamı Bayram Demiral kişisel arşivine aittir. 